\title{
Animal heat activated cancer therapy by a traditional catalyst $\mathrm{TiO}_{2}-\mathrm{Pd} / \mathrm{graphene}$ composites
}

\author{
Yanlong Yu ${ }^{1,3}$, Pengchong Jiang ${ }^{1}$, Yabin Yan ${ }^{1}$, Hanbo Li ${ }^{1}$, Lixin Zhang ${ }^{1}$, Shan Jiang ${ }^{2}$, \\ Wensheng Yang ${ }^{2}$ \& Yaan $\mathrm{Cao}^{1}$
}

Cancer therapy is one of the most important challenges in clinical medicine. So far different methods have been developed for cancer therapy, such as radiation therapy, surgery, chemotherapy and photodynamic therapy. Here we propose a new concept for cancer therapy, i.e., killing the cancer cells simply via reactive oxygen species (ROS) generated by $\mathrm{TiO}_{2}-\mathrm{Pd} / \mathrm{graphene}$ composites. Activated by animal heat of $37^{\circ} \mathrm{C}$, the electrons in the valence band can be excited to the conduction band of $\mathrm{TiO}_{2}$ via the energy levels of Pd species and graphene, generating ROS without light irradiation or electric excitation. The tumors in BALB/c mice are successfully regressed at animal heat without any other external conditions, such as radiation, UV, visible and IR irradiation. Our results suggest that the design of animal heat activated cancer therapy is a feasible concept for practical applications of cancer treatments.

Cancer can be usually treated by surgery, chemotherapy, radiation therapy, hormonal therapy, targeted therapy (including immunotherapy such as monoclonal antibody therapy) and synthetic lethality ${ }^{1-7}$. The choice of therapy depends upon the location and grade of the tumor and the stage of the disease, as well as the general state of the patient (performance status). However, there are still serious side effects for these cancer treatment methods, which may cause damage on human bodies. Therefore, designing and developing new concept about the complete removal of the cancer without damage to the rest of the body is still the ideal goal of treatment.

During the last decades, many photosensitizers have been employed extensively for photodynamic therapy ${ }^{8-10}$. It is known that photodynamic catalyst can generate charge carriers and then produce reactive oxygen species (ROS) on surface under irradiation. These ROS can damage biological DNA and proteins, damaging and killing the cancer cells eventually ${ }^{3,6}$. In addition, photothermal treatment uses near-infrared absorbing nanoparticles to generate heat, resulting in thermal ablation to kill cancer cells. CuS@MSN based theranostic nanoparticles have been designed and synthesized for tumor vasculature targeting and photothermal therapy ${ }^{2}$. The $\mathrm{Au}-\mathrm{Cu}$ nanocrystals exhibit a notable photothermal effect to kill cancer cells irradiated by a $808 \mathrm{~nm}$ laser ${ }^{11}$. However, irradiation necessarily used for photodynamic and photothermal cancer treatment is difficult to be applied in vivo system. Therefore, it is of great importance to design and develop new cancer therapy concepts without any additional irradiation.

Herein, we introduced a new concept, animal heat activated cancer therapy with a traditional catalyst. The ROS can be generated by $\mathrm{TiO}_{2}-\mathrm{Pd} /$ graphene without any external conditions, which could kill the cancer cells and regress the tumors in $\mathrm{BALB} / \mathrm{c}$ mice under animal heat $\left(37^{\circ} \mathrm{C}\right)$, implying the feasibility of brand new concept for the cancer treatment. This concept may possess potential advantages for the practical cancer therapy, such as less body damage, selectivity on killing cancer cells and normal body cells.

\section{Results and discussion}

Raman spectra, XPS and HRTEM are applied to investigate the structure of $\mathrm{TiO}_{2}-\mathrm{Pd} /$ graphene . As shown in Fig. 1A, the Raman peaks of anatase at $144 \mathrm{~cm}^{-1}(\mathrm{Eg}), 194 \mathrm{~cm}^{-1}(\mathrm{Eg}), 396 \mathrm{~cm}^{-1}(\mathrm{~B} 1 \mathrm{~g}), 516 \mathrm{~cm}^{-1}$ (A1g and B1g), and $638 \mathrm{~cm}^{-1}(\mathrm{Eg})$ are observed in $\mathrm{TiO}_{2}$ and $\mathrm{TiO}_{2}-\mathrm{Pd}$ samples. For $\mathrm{TiO}_{2} /$ graphene and $\mathrm{TiO}_{2}-\mathrm{Pd} / \mathrm{Graphene}$, besides the Raman peaks of anatase, the peaks of reduced graphene at 1315 and $1585 \mathrm{~cm}^{-1}$ are detected ${ }^{12,13}$. Similar

${ }^{1}$ Key Laboratory of Weak-Light Nonlinear Photonics, Ministry of Education, TEDA Applied Physics Institute and School of Physics, Nankai University, Tianjin 300457, People's Republic of China. ${ }^{2}$ College of Chemistry, Jilin University, Changchun 130012, People's Republic of China. ${ }^{3}$ Faculty of Mathematics and Physics, Huaiyin Institute ofTechnology, Huaian 223003, China. ${ }^{\boxplus}$ email: caoya@nankai.edu.cn 

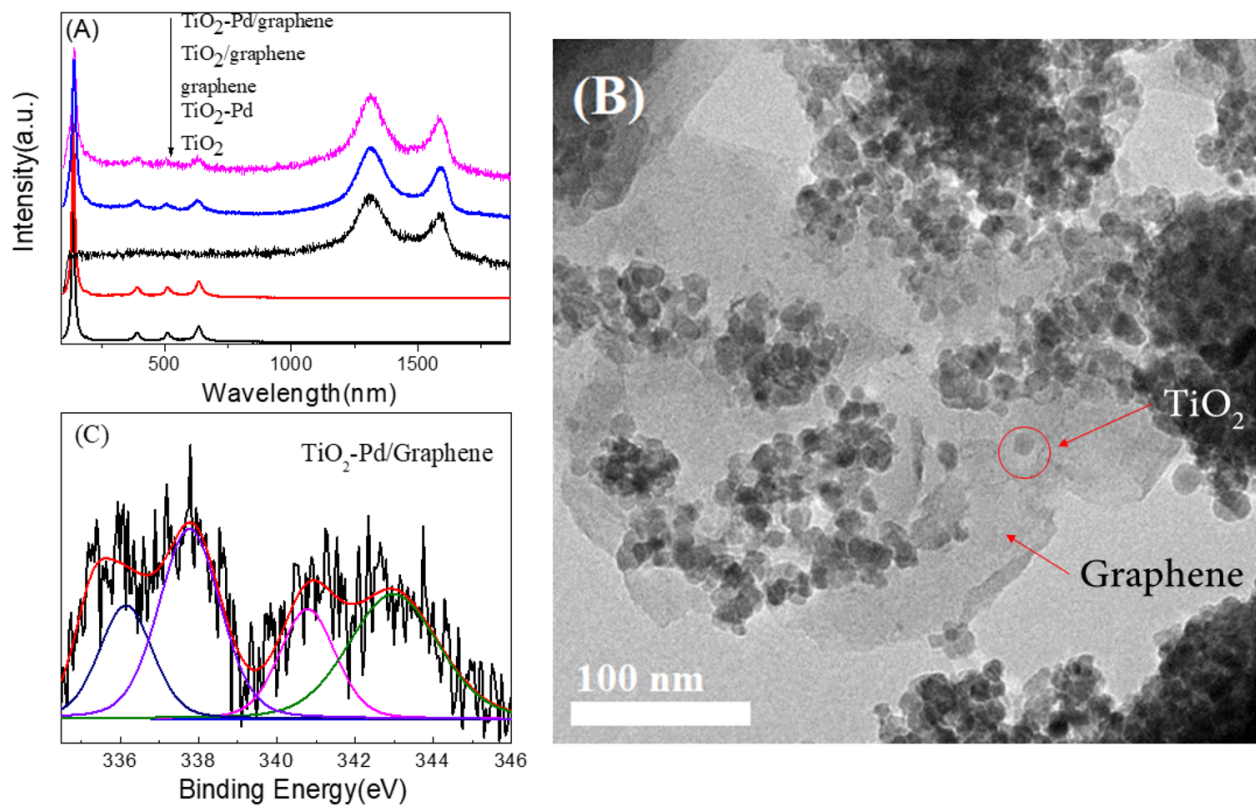

Figure 1. (A) Raman spectra of $\mathrm{TiO}_{2}$, graphene, $\mathrm{TiO}_{2}$ /graphene, $\mathrm{TiO}_{2}-\mathrm{Pd}$ and $\mathrm{TiO}_{2}-\mathrm{Pd} /$ graphene samples. (B) HRTEM images of $\mathrm{TiO}_{2}-\mathrm{Pd} /$ graphene (C) XPS Pd 3d spectrum of $\mathrm{TiO}_{2}-\mathrm{Pd} /$ graphene.

results are obtained from the XRD patterns (Fig. S1). No other XRD peaks, such as PdO can be observed. The cell volume and lattice parameters of $\mathrm{TiO}_{2}-\mathrm{Pd} \mathrm{x} \%$ and $\mathrm{TiO}_{2}-\mathrm{Pd} / \mathrm{Graphene} \mathrm{x} \%$ derived from $\mathrm{XRD}$ data remain almost unchanged (Fig. S2 and Table S1) compared with $\mathrm{TiO}_{2}$. This suggests that Pd ions are not doped into $\mathrm{TiO}_{2}$ lattice in substitutional or interstitial mode, as the ionic radius of $\mathrm{Pd}^{2+}(86 \mathrm{pm})$ is much larger than that of $\mathrm{Ti}^{4+}$ ions $(68 \mathrm{pm})$. Therefore, it can be deduced that the Pd ions might exist on the surface of $\mathrm{TiO}_{2}$. Moreover, according to the XPS results, the $\mathrm{Cl} 2 p_{3 / 2}$ peaks $\left(198.5 \mathrm{eV}\right.$ ) for $\mathrm{TiO}_{2}-\mathrm{Pd} / \mathrm{Graphene}$ (Fig. S3A) locates between that of $\mathrm{TiCl}_{4}(198.2 \mathrm{eV})$ and $\mathrm{PdCl}_{2}(198.9 \mathrm{eV})$, ascribed to the surface $\mathrm{O}-\mathrm{Pd}-\mathrm{Cl}$ structure ${ }^{14}$. Two pairs of doublet $\mathrm{Pd} 3 \mathrm{~d}$ peaks can be observed for $\mathrm{TiO}_{2}-\mathrm{Pd} / \mathrm{Graphene}$ (Fig. 1C). One $\mathrm{Pd} 3 \mathrm{~d}_{5 / 2}$ peak at $337.7 \mathrm{eV}$ is attributed to $-\mathrm{O}-\mathrm{Pd}-\mathrm{Cl}$ structure (i.e., one $\mathrm{Pd}^{2+}$ ion is linked with one $\mathrm{Cl}^{-}$ion and one unsaturated oxygen ion) on the surface. The other peak at $336.2 \mathrm{eV}$ for $\mathrm{Pd} 3 \mathrm{~d}_{5 / 2}$ is ascribed to $-\mathrm{O}-\mathrm{Pd}-\mathrm{O}-$ species on the surface (i.e., one $\mathrm{Pd}^{2+}$ ion is linked with two unsaturated oxygen ions, which has been confirmed by our previous work ${ }^{14}$ ). The molar ratio of $\mathrm{Pd} / \mathrm{Ti}$ for $\mathrm{TiO}_{2}-\mathrm{Pd}$ and $\mathrm{TiO}_{2}-\mathrm{Pd} /$ graphene is $4.19 \% / 100 \%$ and $4.14 \% / 100 \%$, respectively. Moreover, the $\mathrm{C} 1 \mathrm{~s}$ peak at $284.3 \mathrm{eV}$ (Fig. S3B) is ascribed to the graphene. HRTEM image of $\mathrm{TiO}_{2}-\mathrm{Pd} / \mathrm{Graphene}$ (Fig. 1B) confirms $\mathrm{TiO}_{2}-\mathrm{Pd}$ nanoparticles are attached on the surface of graphene. In addition, the peak of $1216 \mathrm{~cm}^{-1}$ in the FR-IR spectra of $\mathrm{TiO}_{2}-\mathrm{Pd} / \mathrm{Graphene}$ is ascribed to vibration of $\mathrm{C}-\mathrm{O}$ bond (Fig. S5). The XPS Ti $2 p$ spectra (Fig. S24 and S25) also confirms the graphene and $\mathrm{TiO}_{2}-\mathrm{Pd}$ are connected via the $\mathrm{Ti}-\mathrm{O}-\mathrm{C}$ bonds.

The surviving fraction of the A549 cells was measured by standard 3-(4,5-dimethylthiazol-2-yl)-2,5-diphenyltetrazolium bromide (MTT) assay to evaluate the ability of killing cancer cells for all samples at $37^{\circ} \mathrm{C}$, as shown in Fig. 2A. The surviving fraction of the A549 cells is about $96 \%$ for $\mathrm{TiO}_{2}, 85 \%$ for graphene, $71 \%$ for $\mathrm{TiO}_{2} /$ graphene, $53 \%$ for $\mathrm{TiO}_{2}-\mathrm{Pd}$ and $16 \%$ for $\mathrm{TiO}_{2}-\mathrm{Pd} /$ graphene, respectively, when the concentration is $25 \mu \mathrm{g} /$ $\mathrm{ml}$ after $16 \mathrm{~h}$ of incubation at $37^{\circ} \mathrm{C}$. Moreover, it is found that the surviving fraction of cancer cells (16\%) for $\mathrm{TiO}_{2}-\mathrm{Pd}$ /graphene is about $1 / 5$ times as that for pure $\mathrm{TiO}_{2}$. With the increase of sample concentration, the performance of killing cancer cells falls in order of $\mathrm{TiO}_{2}<$ graphene $<\mathrm{TiO}_{2} /$ graphene $<\mathrm{TiO}_{2}-\mathrm{Pd}<\mathrm{TiO}_{2}-\mathrm{Pd}$ /graphene. Furthermore, we have also checked the surviving fraction of cancer cells treated with $\mathrm{TiO}_{2}-\mathrm{Pd} \times \%$ and $\mathrm{TiO}{ }_{2}-\mathrm{Pd} /$ graphene $\mathrm{x} \%$ and the surviving fraction is the lowest for $\mathrm{TiO}_{2}-\mathrm{Pd} 1.5 \%$ and $\mathrm{TiO}_{2}-\mathrm{Pd} /$ graphene $40 \%$ (Fig. S6). Furthermore, the increased Pd content $(>1.5 \%)$ and graphene content $(>40 \%)$ would inhibit the performance of killing cancer cells. Thus, the introduced $\mathrm{Pd}$ species and graphene into $\mathrm{TiO}_{2}$ system is the important key factor for the improved ability of killing cancer cells. The optical microscopy images of A549 cancer cells in the presence of samples $(100 \mu \mathrm{g} / \mathrm{mL})$ are shown in Fig. S9. Most of the A549 cells survive well in the blank experiment (without the addition of any samples) (Fig. S9a). The $\mathrm{TiO}_{2}$ can hardly influence the surviving of the cancer cells (Fig. S9b). It is found that the relative amount of healthy cancer cells decreased for $\mathrm{TiO}_{2}$ /graphene (Fig. S9c) and $\mathrm{TiO}_{2}-\mathrm{Pd}$ (Fig. S9d). As we expected, seldom healthy cancers cell can be observed in Fig. S9e for $\mathrm{TiO}_{2}-\mathrm{Pd} /$ graphene samples, suggesting its high efficiency on killing cancer cells. These results are in good agreement with MTT results in Fig. 2A.

The effect of temperature on the surviving fraction of cancer cells treated with various concentration of $\mathrm{TiO}_{2}-\mathrm{Pd} /$ graphene for $4 \mathrm{~h}$ is evaluated in Fig. 2B. The surviving fraction of cancer cells for $\mathrm{TiO}_{2}-\mathrm{Pd} /$ graphene decreased with the increased system temperature. When the concentration of $\mathrm{TiO}_{2}-\mathrm{Pd} / \mathrm{Graphene}$ is about $25 \mu \mathrm{g} /$ $\mathrm{mL}$, the surviving fraction of A549 cells are approximately $80 \%, 70 \%, 60 \%, 55 \%$, and $50 \%$ at $4,12,25,37$ and $39^{\circ} \mathrm{C}$, respectively. Similar results are observed in the synovial cells (Fig. S7). This indicates the system 


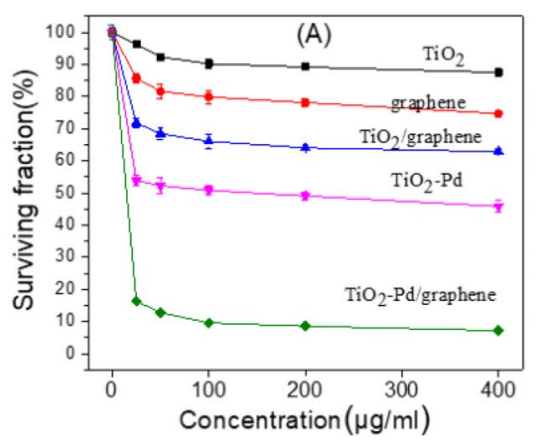

(D) Injected
with PBS
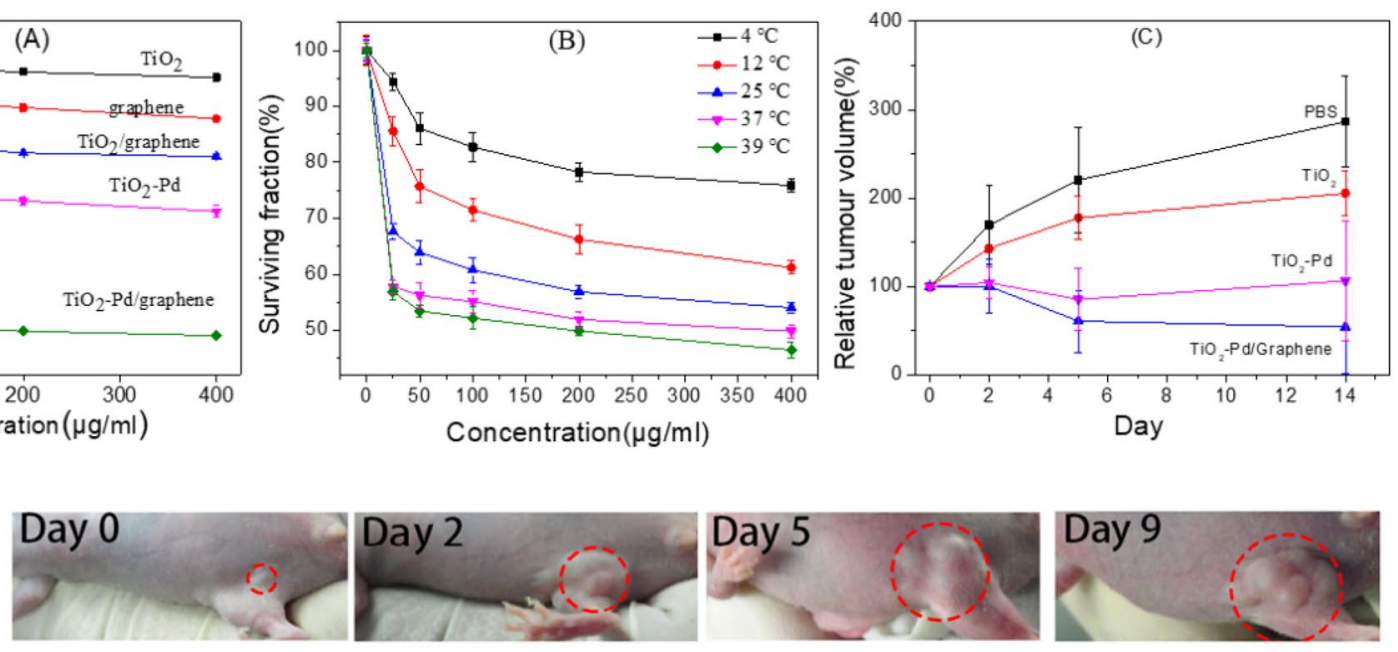

\author{
Injected with \\ $\mathrm{TiO}_{2}-\mathrm{Pd} / \mathrm{Graphene}$
}
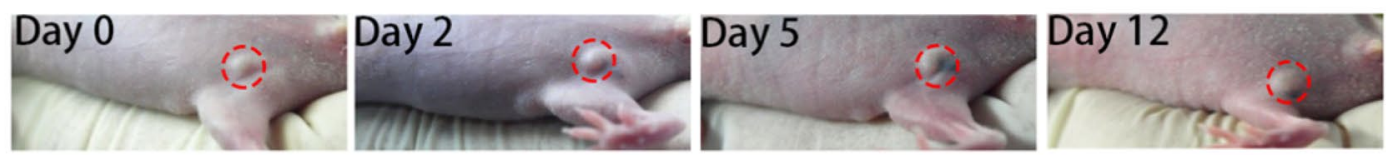

Figure 2. (A) Variations in surviving fraction of $\mathrm{A} 549$ cells with the concentraions of $\mathrm{TiO}_{2}$, graphene, $\mathrm{TiO}_{2} /$ graphene, $\mathrm{TiO}_{2}-\mathrm{Pd}$ and $\mathrm{TiO}_{2}-\mathrm{Pd} /$ graphene at $37^{\circ} \mathrm{C}$ for $16 \mathrm{~h}$. (B) Variations in surviving fraction of A549 cells with the concentration of $\mathrm{TiO}_{2}-\mathrm{Pd} /$ graphene at different temperatures for $4 \mathrm{~h}$. (C) Tumor volume growth curves on mice after treatment with different samples. Error bars were based on s.d. of 3 mice per group. (D) Representative photos of tumors on mice after various treatments indicated.

temperature has great influence on the activity of killing cancer cells for $\mathrm{TiO}_{2}-\mathrm{Pd} /$ graphene, and $\mathrm{TiO}_{2}-\mathrm{Pd} / \mathrm{gra}-$ phene can effectively inhibit the growth of cells at animal heat condition $\left(37^{\circ} \mathrm{C}\right)$.

Fig. S8 shows the relationship between the surviving fraction of the different (A549 and smooth muscle cells) cells and concentration of $\mathrm{TiO}_{2}-\mathrm{Pd} /$ graphene. It is found that only about $10 \%$ of cancer cells survived and $40 \%$ of smooth muscle cells survived at $37^{\circ} \mathrm{C}$ for $16 \mathrm{~h}$ with a concentration of $25 \mu \mathrm{g} / \mathrm{mL}$. This suggests a possible selectivity on cancer therapy for $\mathrm{TiO}_{2}-\mathrm{Pd} /$ graphene. It is expected that further investigation should be carried out by combining other techniques, such as targeted therapy, tumor injection, magnetic control to avoid the side effects on normal cells.

For in vivo animal heat activated therapy study, we employed subcutaneous $4 \mathrm{~T} 1$ xenograft model in BALB/c mice to study the efficacy of animal heat activated cancer therapy $\left(37^{\circ} \mathrm{C}\right.$ ) after treatment by PBS (phosphate buffer saline), $\mathrm{TiO}_{2}, \mathrm{TiO}_{2}-\mathrm{Pd}$ and $\mathrm{TiO}_{2}-\mathrm{Pd} /$ graphene. Twelve tumor-bearing mice were randomly and evenly divided into four groups, which were intratumorally injected with $\mathrm{PBS}, \mathrm{TiO}_{2} \mathrm{TiO}_{2}-\mathrm{Pd}$ and $\mathrm{TiO}_{2}-\mathrm{Pd}$ /graphene, respectively. Figure $2 \mathrm{C}$ shows the thorough regression of tumor volume is observed only in the group with intratumoral injection of $\mathrm{TiO}_{2}-\mathrm{Pd} /$ graphene, while the volume of tumor increases for the group with $\mathrm{PBS}$ and $\mathrm{TiO}_{2}$ and remains unchanged for the group with $\mathrm{TiO}_{2}-\mathrm{Pd}$. For the group with intratumoral injections of $\mathrm{TiO}_{2}-\mathrm{Pd} / \mathrm{graphene}$, the average relative tumor volume decreased to approximately $50 \%$ and for the group with intratumoral injections of $\mathrm{TiO}_{2}-\mathrm{Pd}$, the average relative tumor volume remains almost unchanged. Figure $2 \mathrm{D}$ displays the representative photographs of tumors on mice that the intratumorally injected with $\mathrm{PBS}$ control and $\mathrm{TiO}_{2}-\mathrm{Pd} / \mathrm{graphene}$. The growth of tumor is inhibited when injected with $\mathrm{TiO} 2-\mathrm{Pd} /$ graphene. These experiment results indicate that $\mathrm{TiO}_{2}-\mathrm{Pd}$ /graphene is an effective functional material to inhibit cancer growth under animal heat $\left(37^{\circ} \mathrm{C}\right)$ without external irradiation or heating.

To get the physical insight of the band structure and density of states for $\mathrm{TiO}_{2}-\mathrm{Pd} /$ graphene, the theoretical calculation results of pure $\mathrm{TiO}_{2}, \mathrm{TiO}_{2}-\mathrm{Pd}$ and graphene are shown in Fig. S12-S15. Pure $\mathrm{TiO}_{2}$ indicates an indirect band gap of $2.46 \mathrm{eV}$ (Fig. S12). The zero point corresponds to highest state level that electrons occupy. For $\mathrm{TiO}_{2}-\mathrm{Pd}$, some new quasi-continuous energy levels in the band gap (Fig. S13 and S14) are attributed to the contribution of $-\mathrm{O}-\mathrm{Pd}-\mathrm{Cl}$ and $\mathrm{O}-\mathrm{Pd}-\mathrm{O}$ species. Meanwhile, it is obvious that the states of $\mathrm{Pd} 4 d$ for $-\mathrm{O}-\mathrm{Pd}-\mathrm{Cl}$ and $\mathrm{O}-\mathrm{Pd}-\mathrm{O}$ species plays a great role to make the slightly connection between the conduction band and valence band. For $\mathrm{TiO}_{2}$-Pd (Fig. S13 and S14), the density of states for the conduction band and valence band overlapped with that for the energy levels of Pd species ( $\mathrm{Pd} 4 d$ ), implying that the electrons in the valence band can transfer to the energy levels of Pd species (Pd $4 d$ ) or even conduction band excited by external energy. Moreover, the grapheme (Fig. S15) exhibit as a zero-gap semiconductor, implying electrons can transfer freely in the energy band of graphene ${ }^{15}$. These theory calculation results imply that the electrons can easily transfer between $\mathrm{TiO}_{2}-\mathrm{Pd}$ and graphene when $\mathrm{TiO}_{2}-\mathrm{Pd} / \mathrm{Graphene}$ are excited by external energy such as animal heat. These thermal excited electrons and holes can transfer to the surface to further generate ROS. This theoretical calculation can be further demonstrated by the UV - Vis absorption spectra and XPS valence band spectra (Fig. S16-S18). 
(A)

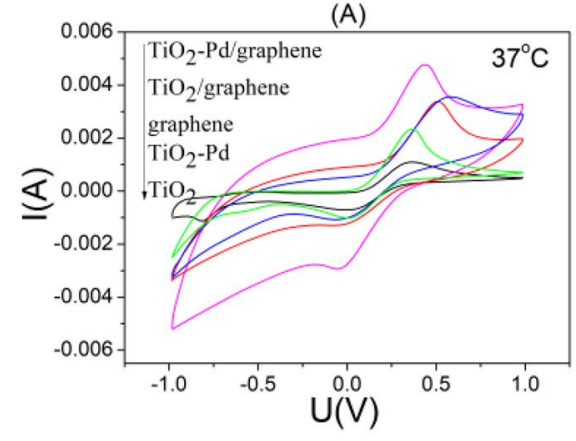

(B)

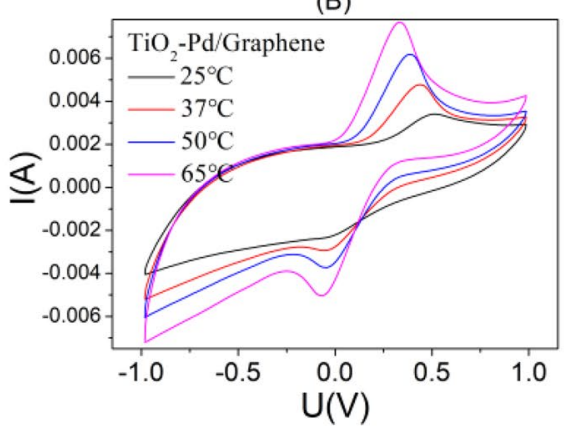

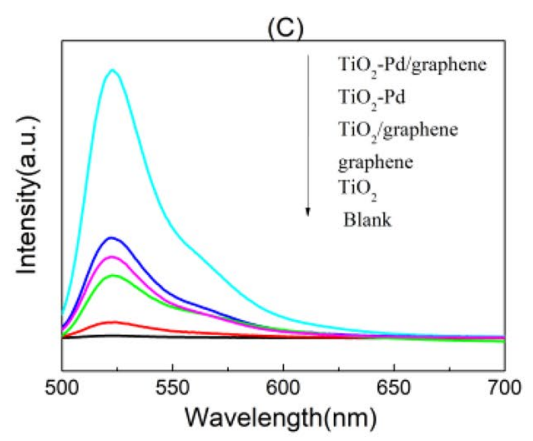

(D)
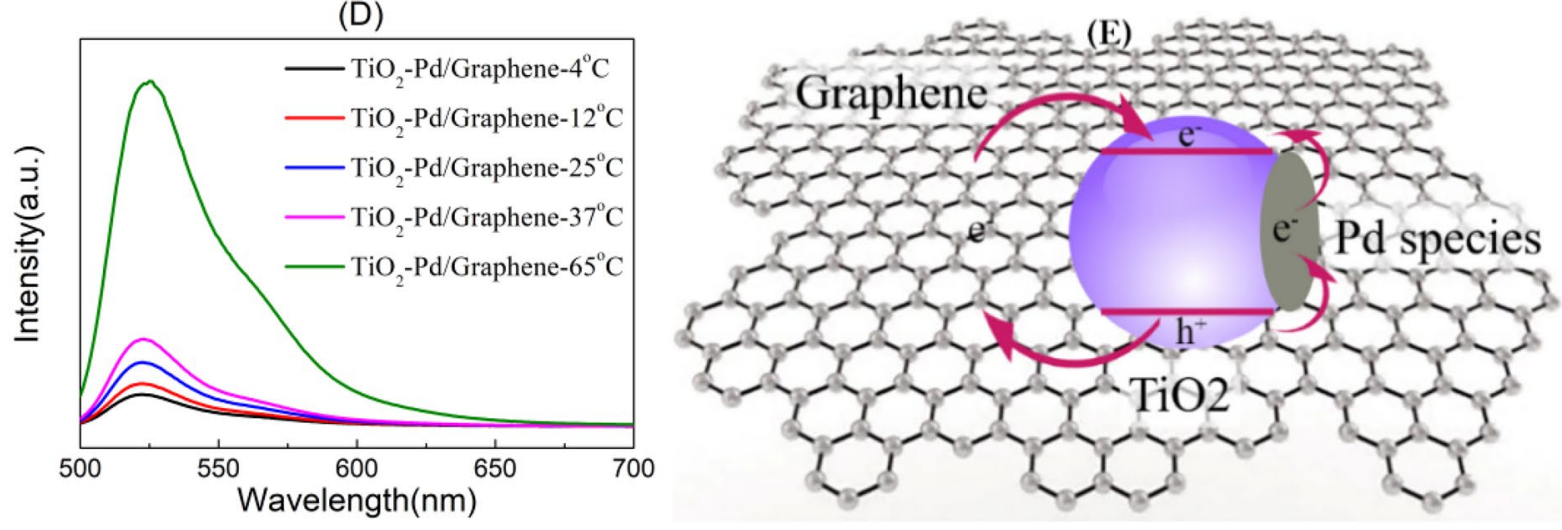

Figure 3. Cyclic voltammetry of all samples at $37^{\circ} \mathrm{C}(\mathrm{A})$ and $\mathrm{TiO}_{2}-\mathrm{Pd} /$ graphene at different temperature (B). Verification of $\mathrm{ROS}$ generation ability for all samples at $37^{\circ} \mathrm{C}(\mathbf{C})$ and $\mathrm{TiO}_{2}-\mathrm{Pd} / \mathrm{Graphene}$ at different temperatures $(\mathbf{D})$. Schematic band structure of $\mathrm{TiO}_{2}-\mathrm{Pd} /$ graphene composite $(\mathbf{E})$.

In Fig. S16, according to the above theory calculation, the stronger absorption in visible region for $\mathrm{TiO}_{2}-\mathrm{Pd}$ is caused by the electron transition from valence band to the quasi-continuous energy levels of Pd species $(\operatorname{Pd} 4 d)$ or from the quasi-continuous energy levels of Pd species ( $\mathrm{Pd} 4 d$ ) to the conduction band. Moreover, for $\mathrm{TiO}_{2} /$ graphene and $\mathrm{TiO}_{2}-\mathrm{Pd} /$ graphene, the strong absorption in visible region is due to the continuous energy band structure of graphene.

For XPS valence band spectra (Fig. S18; the work function of instrument: $4.10 \mathrm{eV}$ ), the valence band top for pure $\mathrm{TiO}_{2}$ is $2.75 \mathrm{eV}(2.35 \mathrm{eV}$; vs $\mathrm{NHE})$, and the highest occupied state level for graphene is about $2.29 \mathrm{eV}$ $\left(1.89 \mathrm{eV}\right.$; vs NHE). For $\mathrm{TiO}_{2}-\mathrm{Pd}$, the valence band top is almost the same as that of $\mathrm{TiO}_{2}$, and a small hump from 2.75 to $0.10 \mathrm{eV}$ ( 2.35 to $-0.3 \mathrm{eV}$ vs NHE) is attributed to the energy level of Pd species (Pd $4 d$ ) occupied by electrons. For $\mathrm{TiO}_{2}-\mathrm{Pd} /$ graphene, the highest energy levels that electrons occupy extend to $-0.6 \mathrm{~V}(-1.0 \mathrm{eV}$; vs $\mathrm{NHE}$ ), owing to the synergetic effect of graphene and $\mathrm{TiO}_{2}-\mathrm{Pd}$. These results imply the electrons in the valence band can transfer to the energy levels of $\mathrm{Pd}$ species $\left(\mathrm{Pd} 4 d\right.$ ) or even the conduction band of $\mathrm{TiO}_{2}$ through the quasi-continuous energy levels freely and continuous energy band structure of graphene excited by the external energy. According to the results, the schematic band structure is determined for $\mathrm{TiO}_{2}-\mathrm{Pd} /$ graphene, as shown in Fig. 3E.

The Raman spectra, cyclic voltammetry curves and fluorescence spectra of the DCF are applied to investigate the relationship between the generation of ROS and temperature. The Raman spectra of $\mathrm{TiO}_{2}-\mathrm{Pd}$ and $\mathrm{TiO}_{2}-\mathrm{Pd} /$ graphene (Fig. S19) indicates the peak intensity was enhanced with the increase of temperature, suggesting an enhanced vibrating energy of lattice, benefiting the electrons' transfer to surface of sample.

The cyclic voltammetry curves of pure $\mathrm{TiO}_{2}$, graphene, $\mathrm{TiO}_{2} /$ graphene, $\mathrm{TiO}_{2}-\mathrm{Pd}$ and $\mathrm{TiO}_{2}-\mathrm{Pd} /$ graphene at $37^{\circ} \mathrm{C}$ (in Fig. 3A) indicate the ability to give and receive electrons increases when Pd species and/or graphene are introduced into $\mathrm{TiO}_{2}$ system. For the cyclic voltammetry curves of the $\mathrm{TiO}_{2}-\mathrm{Pd} /$ graphene at different temperatures, the redox peaks of $\mathrm{TiO}_{2}-\mathrm{Pd} /$ graphene are improved with the increase of temperature (Fig. 3B). This suggests that $\mathrm{TiO}_{2}-\mathrm{Pd} / \mathrm{Graphene}$ may exhibit enhanced ability to give and receive electrons under thermal excitation.

The amounts of $\mathrm{ROS}\left(\cdot \mathrm{OH}, \mathrm{O}_{2}^{-}\right.$, et al.) generated by $\mathrm{TiO}_{2}$, graphene, $\mathrm{TiO}_{2} /$ graphene, $\mathrm{TiO}_{2}-\mathrm{Pd}$ and $\mathrm{TiO}_{2}-\mathrm{Pd} /$ graphene at $37^{\circ} \mathrm{C}$ were evaluated by the photoluminescence (PL) intensity of the DCF (Fig. 3C). No PL peak is detected in the blank experiment. For $\mathrm{TiO}_{2}$ and graphene, a weak PL peak is found, suggesting a small amount of ROS formed. Moreover, for $\mathrm{TiO}_{2} /$ graphene and $\mathrm{TiO}_{2}-\mathrm{Pd}$, the PL intensity further increases, suggesting more $\mathrm{ROS}$ can be generated than $\mathrm{TiO}_{2}$. The $\mathrm{PL}$ intensity for $\mathrm{TiO}_{2}-\mathrm{Pd} /$ graphene is the strongest among all the samples, indicating $\mathrm{TiO}_{2}-\mathrm{Pd} /$ graphene is most effective to generate $\mathrm{ROS}$ among all the samples at $37^{\circ} \mathrm{C}$. Figure $3 \mathrm{D}$ shows generation amount of $\mathrm{ROS}$ for $\mathrm{TiO}_{2}-\mathrm{Pd} /$ graphene at different temperatures. It is noted that the PL intensity significantly increases with the increase of temperature, indicating the increased temperature is benefit for the generation of reactive oxidation species. This also confirms that the electrons and holes in $\mathrm{TiO}_{2}$ can be excited by heat and transfer to surface to form ROS. 
Based on the aforementioned discussion, the mechanism of generating ROS (such as $\cdot \mathrm{OH}, \mathrm{O}_{2}^{-}$) and kill the cancer cells for all samples can be explained using the schematic band structure shown in Fig. 3E. The electrons in the conduction band $\left(-0.45 \mathrm{eV}\right.$, vs NHE) excited by animal heat $\left(37^{\circ} \mathrm{C}\right)$, whose potential is more negative than that of $\mathrm{O}_{2} / \mathrm{O}_{2}^{-}(-0.33 \mathrm{eV}$, vs $\mathrm{NHE})$, can transfer to the surface and directly captured by the adsorbed $\mathrm{O}_{2}$ molecules on the surface to form $\mathrm{O}_{2}{ }^{-}$active species as shown in Eq. $(1)^{16-18}$. The holes in the valence band $(+2.65 \mathrm{eV}$, vs NHE), whose potential is more positive than $\mathrm{H}_{2} \mathrm{O} / \mathrm{H}^{+}\left(0.82 \mathrm{~V}\right.$, vs NHE), are captured by surface absorbed $\mathrm{H}_{2} \mathrm{O}$ molecules to form $\mathrm{O}_{2}$ and $\mathrm{H}^{+}$, which can further react with thermal electrons to produce the hydroxyl free radical $\mathrm{OH} \cdot$ as shown in Eqs. (2), (3) and (4) ${ }^{16-18}$.

$$
\begin{gathered}
\mathrm{O}_{2}+\mathrm{e}=\mathrm{O}_{2}^{-} \\
\mathrm{E}_{\text {redox }}^{\mathrm{o}}=-0.33 \mathrm{~V} \text { vs NHE } \\
2 \mathrm{H}_{2} \mathrm{O}+4 \mathrm{~h}^{+} \rightarrow \mathrm{O}_{2}+4 \mathrm{H}^{+} \\
\mathrm{E}_{\text {redox }}^{\mathrm{o}}=0.82 \mathrm{~V} \text { vs NHE } \\
\mathrm{O}_{2}+2 \mathrm{H}^{+}+2 \mathrm{e}=\mathrm{H}_{2} \mathrm{O}_{2} \\
\mathrm{H}_{2} \mathrm{O}_{2}+\mathrm{e}=\mathrm{OH}^{-}+\mathrm{HO}^{\circ} \\
\mathrm{OH}^{-}+\mathrm{h}^{+}=\mathrm{HO}^{.}
\end{gathered}
$$

For pure $\mathrm{TiO}_{2}$, electrons can hardly be excited to the conduction band by the animal heat $\left(37^{\circ} \mathrm{C}\right)$, leading to a poor killing cancer cell activity, because of large band gap $(3.0 \mathrm{eV})$. For $\mathrm{TiO}_{2}-\mathrm{Pd}$, a small amount of electrons can be excited by the animal heat and transfer to the conduction band through the quasi-continuous energy levels of $\mathrm{Pd}$ species, leaving holes in the valence band of $\mathrm{TiO}_{2}$. For $\mathrm{TiO}_{2} /$ graphene, the electrons could also be excited by the animal heat and transfer to the conduction band of $\mathrm{TiO}_{2}$ through the continuous energy levels of graphene, leaving holes in the valence band of $\mathrm{TiO}_{2}$. The electrons and holes would react with adsorbed $\mathrm{O}_{2}$ and $\mathrm{H}_{2} \mathrm{O}$ molecules on surface to form a small amount of ROS, which would kill the cancer cells directly. For $\mathrm{TiO}_{2}-\mathrm{Pd} / g r a p h e n e$, the electrons in the valence band can accept the energy from the animal heat and transfer to the conduction band through the quasi-continuous energy levels of Pd species and the continuous energy levels of graphene, generating more charge carriers than $\mathrm{TiO}_{2}-\mathrm{Pd}$ and $\mathrm{TiO}_{2}$ /graphene. Therefore, more ROS can be produced and the $\mathrm{TiO}_{2}-\mathrm{Pd}$ /graphene exhibited the better capability of killing cancer cells than the other samples.

In summary, we have demonstrated a new concept for developing high efficient animal heat activated cancer treatment for $\mathrm{TiO}_{2}-\mathrm{Pd} /$ graphene. The electrons and holes can be excited through the energy levels of Pd species and graphene at animal heat, generating ROS which can further kill the cancer cells. This may afford a feasible and efficient approach for cancer therapy application, without any other external conditions such as radiation, $\mathrm{UV}$, visible and IR irradiation that may cause serious body damage.

\section{Methods}

Catalyst preparation. Synthesis of $\mathrm{Pd}-\mathrm{TiO}_{2}$. All chemicals used were of analytical grade and the water was deionized water $(>18.2 \mathrm{M} \Omega \mathrm{cm})$. At room temperature, certain volume of $\mathrm{PdCl}_{2}(0.1036 \mathrm{~mol} / \mathrm{L})$ solution were mixed with $40 \mathrm{~mL}$ of ethanol. Then $1 \mathrm{~mL}$ of $\mathrm{HCl}$ solution $(12 \mathrm{~mol} / \mathrm{L})$ and $12 \mathrm{~mL}$ of Ti$\left(\mathrm{OC}_{4} \mathrm{H}_{9}\right)_{4}$ was added dropwise into the mixture under vigorous stirring. The mixture was stirred until the formation of $\mathrm{TiO}_{2}$ gel, followed by being aged for $24 \mathrm{~h}$. The obtained gels were dried at $373 \mathrm{~K}$ for $12 \mathrm{~h}$ and annealed at $723 \mathrm{~K}$ in a muffle for $2.5 \mathrm{~h}$. The resultant samples were denoted as $\mathrm{Pd}-\mathrm{TiO}_{2}$. Pure $\mathrm{TiO}_{2}$ was prepared using the same procedure, while without the addition of $\mathrm{PdCl}_{2}$ solution. Unless stated otherwise, the nominal molar ratio of $\mathrm{Pd}^{2+}$ to $\mathrm{Ti}^{4+}$ is fixed at $1.5 \%$ in the precursor and. For comparison, other molar ratios were also used for $\mathrm{Pd}^{2+}$ to $\mathrm{Ti}^{4+}$ (such as $0.5 \%, 1.0 \%, 2.0 \%, 2.5 \%$ and $3.0 \%)$.

Synthesis of graphene oxide (GO). GO was prepared from crystalline flake graphite powder according to the modified method reported by Hummers and Offeman ${ }^{19}$. In brief, $10 \mathrm{~g}$ of graphite powder and $5 \mathrm{~g}$ of $\mathrm{NaNO}_{3}$ were added into $230 \mathrm{~mL}$ of cooled $(273 \mathrm{~K})$ concentrated $\mathrm{H}_{2} \mathrm{SO}_{4}$. Then, $30 \mathrm{~g}$ of $\mathrm{KMnO}_{4}$ was added gradually with continuous stirring and cooling, and the temperature of the mixture was maintained below $293 \mathrm{~K}$. After the ice bath was removed, the mixture was stirred at $308 \mathrm{~K}$ for $30 \mathrm{~min} .460 \mathrm{~mL}$ of distilled water was added slowly to cause an increase in temperature to $371 \mathrm{~K}$, and the mixture was maintained at that temperature for $15 \mathrm{~min}$. The reaction was terminated by addition of $1.4 \mathrm{~L}$ of distilled water followed by $25 \mathrm{~mL}$ of $30 \% \mathrm{H}_{2} \mathrm{O}_{2}$ aqueous solution. The solid product was separated by centrifugation and washed repeatedly with $5 \% \mathrm{HCl}$ solution $(2 \mathrm{~L})$ and deionized water until sulfate anion could not be detected with $\mathrm{BaCl}_{2}$. The resultant solid was dried in vacuum at $323 \mathrm{~K}$ to obtain GO.

Preparation of $\mathrm{TiO}_{2}-\mathrm{Pd} /$ grapheme. GO was first dissolved in deionized water by ultrasonic treatment for $20 \mathrm{~min}$. Then, $\mathrm{Pd}-\mathrm{TiO}_{2}$ was added into the $\mathrm{GO}$ colloidal solution and the mixture was ultrasonic for another $1 \mathrm{~h}$ to obtain a homogeneous suspension. The resultant composite was collected by drying at $333 \mathrm{~K}$ and then 
triturated to powder in an agate mortar. Finally, the powder was calcined at $300{ }^{\circ} \mathrm{C}$ for $2 \mathrm{~h}$ under Ar atmosphere. The resulting products were $\mathrm{TiO}_{2}-\mathrm{Pd} /$ graphene.

Characterizations. The XRD patterns were acquired using a Rigaku D/max 2500 X-ray diffraction spectrometer $(\mathrm{Cu} \mathrm{Ka}, \lambda=1.54056 \AA)$. The average crystallite size was calculated according to the Scherrer formula $(D=\mathrm{k}$ $\lambda / B \cos \theta)$. Raman spectra were taken on a Renishaw inVia Raman microscope by using the $785 \mathrm{~nm}$ line of a Renishaw HPNIR 785 semiconductor laser. The Fourier Transform Infra-Red (FT-IR) spectra were recorded for $\mathrm{KBr}$ disks containing the powder sample with an FT-IR spectrometer (MAGNA-560). The BET surface areas of the samples were determined by nitrogen adsorption-desorption isotherm measurements at $77 \mathrm{~K}$ (Micromeritics Automatic Surface Area Analyzer Gemini 2360, Shimadzu). XPS measurements were carried out by using a Thermo ESCALAB 250 spectrometer with an $\mathrm{Al} \mathrm{Ka}$ monochromator source and all the binding energies were calibrated to the adventitious C1s peak at $284.8 \mathrm{eV}$. Diffuse reflectance UV-visible (UV-Vis) absorption spectra were recorded on a UV-Vis spectrometer (U-4100, Hitachi). ROS in the presence of samples was qualitatively detected by the H2DCF-DA assay. Photoluminescence (PL) spectra were acquired by using the $325 \mathrm{~nm}$ line of a nano-second Nd: YAG laser (NL303G) as excitation source. The experimental setup consists of a spectrometer (Spex 1702), a photomultiplier tube (PMT, Hamamatsu R943), a lock-in amplifier, and a computer for data processing. The cyclic coltammetry curves were measured using an electrochemical workstation (CorrTest, Wuhan, Inc.) in a conventional three-electrode cell at different temperature. The samples/ITO is used as working electrode, $\mathrm{Pt}$ is used as counter electrode and the saturated calomel electrode (SCE) was used as reference electrode. $0.5 \mathrm{mmol} / \mathrm{L} \mathrm{K}_{4}\left[\mathrm{Fe}(\mathrm{CN})_{6}\right]^{+}+0.05 \mathrm{mmol} / \mathrm{L} \mathrm{K}_{3}\left[\mathrm{Fe}(\mathrm{CN})_{6}\right]^{+}+0.1 \mathrm{~mol} / \mathrm{L} \mathrm{KCl}$ aqueous solution was used as electrolyte.

The generation ability of reactive oxygen species (ROS) for thermal catalysts can be estimated by measuring the fluorescent intensity of 2',7'-dichlorofluorescein (DCF). The 2',7'-dichlorodihydrofluorescein (DCFH, nonfluorescent) can rapidly react with ROS in the thermal catalysis system to form $2^{\prime}, 7^{\prime}$-dichlorofluorescein (DCF, fluorescent). By measuring the fluorescent intensity of DCF, the generation ability of ROS can be determined for thermal-catalyst. Experimental process is as follow: $5 \mathrm{mg}$ of catalysts were added into $5 \mathrm{ml}$ centrifuge tube, then $1 \mathrm{ml}$ working solution ( $975 \mu \mathrm{l}$ of diluents and $25 \mu \mathrm{l}$ staining fluid containing DCFH) was added. The mixture was shock and heated at different temperature for $30 \mathrm{~min}$ (room temperature, $65^{\circ} \mathrm{C}$ ). Then, the mixture was centrifuged and the supernatant was taken to detect the fluorescent intensity. The exciting wavelength for exaction is $491 \mathrm{~nm}^{20}$.

Apoptosis assay. Human Lung Carcinoma cells (A549), smooth muscle cells and synovial cells were cultured in RPMI 1640 medium in 96-well plates, containing 10\% fatal calf serum (FCS) in a humidified incubator with an atmosphere of $5 \% \mathrm{CO}_{2}$ in air at $37^{\circ} \mathrm{C}$. The cell density was $2 \times 10^{4}$ cells per well. After being seeded for $24 \mathrm{~h}$, the media were replaced by culture media containing a series of $\mathrm{TiO}_{2}, \mathrm{Pd}-\mathrm{TiO}_{2}$ and $\mathrm{TiO} 2-\mathrm{Pd} / \mathrm{Graphene}$ nanoparticles with increasing concentrations in RPMI 1640 medium and then the plates were placed into the humidified incubator. After another $16 \mathrm{~h}$ for the interaction between the cancer-cells and the nanocomposite particles, cell viabilities were measured by the standard MTT assay, a colorimetric assay based on the ability of viable cells to reduce 3-[4,5-dimethylthiazol-2-yl]-2,5-diphenyltetrazolium bromide. The survival rate and the error bar are shown in Fig. 2B (the case of incubating with nanocrystals only).

In vivo thermal therapy. BALB/c mice bearing A549 lung carcinoma tumors were intratumorally injected with $\mathrm{TiO}_{2}, \mathrm{Pd}-\mathrm{TiO}_{2}$ or graphene $/ \mathrm{Pd}-\mathrm{TiO}_{2}$ (80 ul of $4 \mathrm{mg} / \mathrm{ml}$ solution for each mouse), respectively. The images were taken by an high definition camera. The tumor sizes were measured by a caliper every other day and calculated as volume $=($ tumor length $) \times(\text { tumor width })^{2} / 2$. Relative tumor volumes were calculated as V/V0 $(\mathrm{V} 0$ is the tumor volume when the treatment was initiated). The animal protocol in this study conformed to the Guide for the Care and Use of Laboratory Animals (the Guide, NRC 2011), and it was also approved by the Institutional Animal Care and Use Committee at Nankai University (Approval ID 201009080081).

Supporting information. Thermal catalytic activity, XRD, XPS Cl 2p, PDOS, Absorption spectra, XPS valence band spectra, Raman spectra, PL spectra and thermal excited PL spectra.

Received: 10 January 2020; Accepted: 1 September 2020

Published online: 25 September 2020

\section{References}

1. Ancona, A. et al. Lipid-coated zinc oxide nanoparticles as innovative ROS-generators for photodynamic therapy in cancer cells. Nanomaterials https://doi.org/10.3390/nano8030143 (2018).

2. Chen, F. et al. In vivo tumor vasculature targeting of CuS@MSN based theranostic nanomedicine. ACS Nano 9, 3926-3934. https ://doi.org/10.1021/nn507241v (2015).

3. Duan, D. B. et al. Activating $\mathrm{TiO}_{2}$ nanoparticles: gallium-68 serves as a high-yield photon emitter for cerenkov-induced photodynamic therapy. ACS Appl. Mater. Interfaces 10, 5278-5286. https://doi.org/10.1021/acsami.7b17902 (2018).

4. Han, Y. et al. Theranostic micelles based on upconversion nanoparticles for dual-modality imaging and photodynamic therapy in hepatocellular carcinoma. Nanoscale 10,6511-6523. https://doi.org/10.1039/c7nr09717d (2018).

5. Huang, C.-X. et al. Controlled synthesis of upconverting nanoparticles/CuS yolk-shell nanoparticles for in vitro synergistic photothermal and photodynamic therapy of cancer cells. J. Mater. Chem. B 5, 9487-9496. https://doi.org/10.1039/c7tb02733h (2017).

6. Seo, J. W. et al. Development of water-soluble single-crystalline $\mathrm{TiO}_{2}$ nanoparticles for photocatalytic cancer-cell treatment. Small 3, 850-853. https://doi.org/10.1002/smll.200600488 (2007). 
7. Wu, M.-X. \& Yang, Y.-W. Metal-organic framework (MOF)-based drug/cargo delivery and cancer therapy. Adv. Mater. https:// doi.org/10.1002/adma.201606134 (2017).

8. Dou, Q. Q., Rengaramchandran, A., Selvan, S. T., Paulmurugan, R. \& Zhang, Y. Core-shell upconversion nanoparticle-semiconductor heterostructures for photodynamic therapy. Sci. Rep. https://doi.org/10.1038/srep08252 (2015).

9. Lucky, S. S., Soo, K. C. \& Zhang, Y. Nanoparticles in photodynamic therapy. Chem. Rev. 115, 1990-2042. https://doi.org/10.1021/ cr5004198 (2015).

10. Lismont, M., Dreesen, L. \& Wuttke, S. Metal-organic framework nanoparticles in photodynamic therapy: current status and perspectives. Adv. Funct. Mater. https://doi.org/10.1002/adfm.201606314 (2017)

11. He, R. et al. Facile synthesis of pentacle gold-copper alloy nanocrystals and their plasmonic and catalytic properties. Nat. Commun. https://doi.org/10.1038/ncomms5327 (2014).

12. Xiang, Q., Yu, J. \& Jaroniec, M. Enhanced photocatalytic $\mathrm{H}_{2}$-production activity of graphene-modified titania nanosheets. Nanoscale 3, 3670-3678 (2011).

13. Song, P., Zhang, X., Sun, M., Cui, X. \& Lin, Y. Graphene oxide modified $\mathrm{TiO}_{2}$ nanotube arrays: enhanced visible light photoelectrochemical properties. Nanoscale 4, 1800-1804 (2012).

14. Yu, Y. et al. Efficient visible-light photocatalytic degradation system assisted by conventional Pd catalysis. Sci. Rep. 5(9561), 1-6 (2015).

15. Perdew, J. P. \& Wang, Y. Accurate and simple analytic representation of the electron-gas correlation energy. Phys. Rev. B: Condens. Matter 45, 13244 (1992).

16. Chen, X. \& Mao, S. S. Titanium dioxide nanomaterials: synthesis, properties, modifications, and applications. Chem. Rev. 107, 2891-2959 (2007).

17. Habisreutinger, S. N., Schmidt-Mende, L. \& Stolarczyk, J. K. Photocatalytic reduction of $\mathrm{CO}_{2}$ on $\mathrm{TiO}_{2}$ and other semiconductors. Angew. Chem. Int. Ed. 52, 7372-7408. https://doi.org/10.1002/anie.201207199 (2013).

18. Li, K. F., An, X. Q., Park, K. H., Khraisheh, M. \& Tang, J. W. A critical review of $\mathrm{CO}_{2}$ photoconversion: catalysts and reactors. Catal. Today 224, 3-12. https://doi.org/10.1016/j.cattod.2013.12.006 (2014).

19. Hummers, W. S. \& Offeman, R. E. Preparation of graphitic oxide. J. Am. Chem. Soc 80, 1339 (1958).

20. Lan, Z., Yu, Y., Yao, J. \& Cao, Y. The band structure and photocatalytic mechanism of $\mathrm{MoS}_{2}$-modified $\mathrm{C}_{3} \mathrm{~N}_{4}$ photocatalysts with improved visible photocatalytic activity. Mater. Res. Bull. 102, 433-439. https://doi.org/10.1016/j.materresbull.2018.02.055 (2018).

\section{Acknowledgements}

This work was supported by the National Natural Science Foundation of China (Nos, 51372120, 21872073 and 21805190).

\section{Author contributions}

Y.C. conceived the project and designed the experiments. Y.Y., P.J. and Y.Y. performed the samples preparation, structural characterization, in vivo thermal therapy and apoptosis assay. H.L. and L.Z. performed the theory calculation. S.J. and W.Y. helped and analyzed the paper. Y.Y. and Y.C. wrote this paper.

\section{Competing interests}

The authors declare no competing interests.

\section{Additional information}

Supplementary information is available for this paper at https://doi.org/10.1038/s41598-020-72682-4.

Correspondence and requests for materials should be addressed to Y.C.

Reprints and permissions information is available at www.nature.com/reprints.

Publisher's note Springer Nature remains neutral with regard to jurisdictional claims in published maps and institutional affiliations.

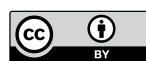

Open Access This article is licensed under a Creative Commons Attribution 4.0 International License, which permits use, sharing, adaptation, distribution and reproduction in any medium or format, as long as you give appropriate credit to the original author(s) and the source, provide a link to the Creative Commons licence, and indicate if changes were made. The images or other third party material in this article are included in the article's Creative Commons licence, unless indicated otherwise in a credit line to the material. If material is not included in the article's Creative Commons licence and your intended use is not permitted by statutory regulation or exceeds the permitted use, you will need to obtain permission directly from the copyright holder. To view a copy of this licence, visit http://creativecommons.org/licenses/by/4.0/.

(c) The Author(s) 2020 